\title{
DERIVING AND INTERPRETING KA(KARIMUSUbi) IN PREMODERN JAPANESE
}

\author{
Moreno MITROVIĆ ${ }^{1}$ \\ University of Cambridge \\ mm821@cam.ac.uk
}

\begin{abstract}
This paper provides a new syntax and semantics for kakarimusubi (KM), a focus construction prominent in the grammar of Old Japanese (OJ) and Early Middle (Classical) Japanese (CJ), which diachronically developed into the interrogative construction in Modern Japanese (MdJ) headed by the $k a$ particle. Adopting Chierchia \& Caponigro's (2013) novel analysis of Free Relatives (FRs) as embedded interrogatives, an FR-based analysis of KM is proposed so as to obtain a compositional semantic analysis of this focus construction as well as an account of the adnominal marking of the presuppositional musubi component of this grammatical construction.
\end{abstract}

Keywords: Old Japanese; syntax-semantics of focus; particles

\section{Povzetek}

Članek predlaga novo skladenjsko in pomenoslovno analizo kakarimusubi-ja, konstrukcije žariščenja, ki je bila prominentna slovnična značilnost v stari japonščini (OJ) ter zgodnjesrednji (klasični) japonščini (CJ) in katera se je diahrono razvila v vprašalno konstrukcijo, izraženo $\mathrm{s}$ členkom $k a$, v moderni japonščini (MdJ). Z usvojitvijo Chierchiove \& Caponigrove (2013) nove analize prostih odvisnih stavkov (FR), po kateri so le-ti sestavljeni iz vprašalnih stavkov, predlagam analizo KM, zasnovano na FR, s katero dosežem sestavno-pomenoslovno analizo te konstrukcije žariščenja kot tudi analizo adnominalnega označevanja na predpostavnem musubi delu te slovnične sestave.

Ključne besede: stara japonščina; skladnja/pomenoslovje žariščenja; slovnični delci

\footnotetext{
${ }^{1}$ The existence of this paper is almost entirely due to the kind and helpful presence of John Whitman who introduced me to Old Japanese during my fellowship at the Naitonal Institute of Japanese Language and Linguistics, Tokyo. Edith Aldridge has provided very helpful and sobering commentary on an earlier draft of this paper. My thanks are also due to Bjarke Frellesvig and Kerri Russel and the rest of the Oxford Old Japanese researchers who have made their incredible corpus avalaible. Reearch reported here has received financial support from the British Arts and Humanities Research Council (AHRC) no. AH/J500094/1, AHRC IPS fellowship grant no. MM821IPS, and the HRDSF grant no. 11010- 542/2011. Errors that remain are mine alone.
} 


\section{Introduction}

This paper provides a novel analysis of the ka-marked kakarimusubi (KM) construction on both syntactic and semantic levels. I first review the synchronic syntactic status of KM in premodern Japanese and account for its diachronic decline in Section 2. Section 3 then translates the motivated syntactic structure into a formal semantic composition. The core analysis will hinge on Chierchia \& Caponigro's (2013) novel analysis of Free Relatives (FRs) as embedded interrogatives. KM will be shown to involve the syntactic structure of a FR which is the derivational source of the adnominal marking on the musubi component. Section 4 concludes the discussion.

\section{The syntax of kakarimusubi and its historical demise}

One of the most exotic and interesting gramamtical structures in OJ is the kakarimusubi (KM) construction. Translating as 'hanging-tying', KM, as Frellesvig (2010: 247) describes it, is a Japanese grammatical term for a specific focus construction, in which some constituent is marked by one of the 'kakari particles' and the core predicate it relates to is in a specific nominal form, rather than in the conclusive form generally used to conclude sentences. Given below is a simple, yet representative, example of KM, taken from Watanabe (2002: 181), where we underline the two crucial components: the co-occurrence of the $k a(\kappa)$ particle and the adnominal inflection on the verb. $^{2}$

$\begin{array}{llll}\text { 敵見有 } & \text { 虎 } & \text { 可 } & \text { 吼登 } \\ \text { atami-taru } & \text { twora } & \text { ka } & \text { poyu-ru } \\ \text { iritated.STAT } & \text { tiger } & \mathbf{\kappa} & \text { roar-ADN }\end{array}$

'Is it [an irritated tiger] $]^{\mathrm{F}}$ that is roaring?' (MYS 2.199)

Frellesvig (2010: 249) elegantly equates kakarimusubi and the theme-rheme construction, which we show in Tab. 1, where topic and focus are seen as forming subtypes of kakarimusubi (theme-rheme).

\footnotetext{
${ }^{2}$ We limit our analysis to $k a$-type KM only. For a wider empirical descriptions of the general phenomenon and recent syntactic analyses, see Whitman (1997); Serafim and Shinzato (2000); Wrona (2007), and the work cited therein.
} 
Table 1: KM as a theme-rheme super-construction .

\begin{tabular}{llll}
\hline [SEGMENT $]$ & Kakari (theme) & Musubi (rheme) \\
\hline [STRUCTURE] & & & \\
\hline [INTERPRETATION] & focus & \\
\hline [FORM] & headed by particle $k a$ & adnominal \\
\hline
\end{tabular}

While prevalent in both OJ and CJ, the KM construction disappears from the language by the Edo period, i.e. by the beginning of the 17 th century as previous diachronic research on the topic has shown (Serafim and Shinzato 2000: 82; Okimori 1989: 95-98).

CJ prose, as Vovin (2003: 431) observes, boasted two interrogative particles: $y a$ and $k a$, which forms the core point of interest in this paper. Ikeda (1975) notes that the $k a$ particle expresses a question aimed at the speaker himself, while the particle ya expresses a question directed at the addressee. Vovin (2003) has subsequently shown that recent investigations of CJ grammar invalidate Ikeda's (1975) original generalisation. While $k a$ may express self-addressing and rhetorical questions, it also expresses questions aimed at the addressee. Same has been shown to hold of the ya particle. On a more morphosyntactic level, ya occurs exclusively in polar questions, while $k a$ tends to be used (not exclusively, however) in combination with $w h$-interrogatives. ${ }^{3}$

(2) Traditional view on the time course of the change (Watanabe 2002: 182)

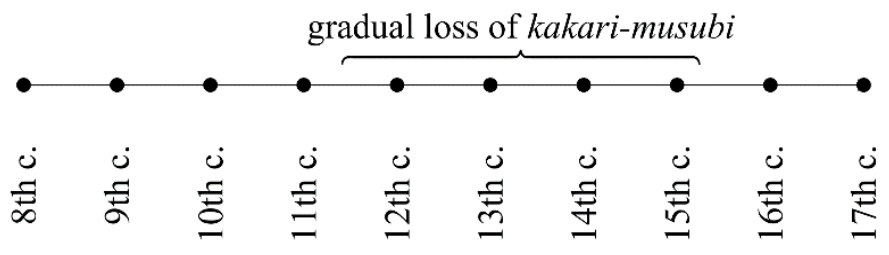

\footnotetext{
${ }^{3}$ This usage of $k a$ in combination with $w h$-phrases, has been observed by Tokieda (1954) and has subsequently received excellent formal diachronic treatments by Watanabe (2002) and, especially, Aldridge (2009).
} 
The particle $k a$, all up until the 17th century, is an exclusive feature of the KM construction, which has an inherently focal semantics. We plot in (2) the time of loss of the KM construction, taken from Watanabe's (2002) work. The synchronic affinity between focus and interrogativity has been recognised since, at least, Erteschik-Shir (1986), who argued for the idea that the $w h$-phrase in a wh-question functions as the focus of the question. This idea, in light of KM, lends itself to a diachronic analysis of Old and Classical Japanese $k a$ which underwent a change from being a focus operator, combining with $w h$-terms, to a question operator. We state this diachronic hypothesis in a more formal term in (3) using a(n interpretable) feature notation (Chomsky 1995, et seq., inter. al.).

\section{OJ/CJ: $k a$ [iFOC] $\gg$ Post-CJ/MdJ: $k a[\mathrm{iQ}]$}

Evindence in (4) demonstrates that $\mathrm{OJ} k a$ was not originally a question particle since interrogative meaning may obtain without $k a$-marking. We reiterate Aldridge's (2009) arguments againsts an interrogative analysis below.

$$
\begin{aligned}
& \text { 伊麻 波伊可爾 世母 } \\
& \text { ima-fa ikani se-mo } \\
& \text { now-TOP how do-SUPP.ADN }
\end{aligned}
$$

'What should we do now?' (MYS 14.3418, 1. 5; from Aldridge 2009: 550)

The focus particle $k a$, as Watanabe (2002: 183) notes, had no restriction to host $w h$ terms in the OJ period (8th c.) since $k a$ was able to host a non-wh-phrase. It was Nomura (1993a, b) who first examined the ordering restriction on the placement of $k a$ within the clause in OJ (MYS), clearly showing that there was a fixed position for the placement $k a$, with regards to other grammatical markers of topichood $(f a)$ and subjecthood $(n o / g a)$. This line of reseach has shown that $k a$ and its host are restricted to a position following the topic marker $f a$ but preceding ( $>$ ) the no/ga-marked subject. Listed in Tab. 2 are Nomura's results as refined by Wrona (2007: 3), who shows several problems with the statistical analysis that Nomura (1993a, b) made and Watanabe (2002) adopted. 
Table 2: The relative order of ka-phrases in MYS ( $\mathrm{p}<0.005)$ as per Nomura (1993b, a) and Wrona (2007) .

token \#

\begin{tabular}{llll}
\hline \multirow{2}{*}{ GENITIVE SUBJECT } & $\begin{array}{l}\text { XP-ka } \\
\text { subject-no/ga }\end{array}$ & $>$ subject-no/ga & $\begin{array}{l}15 \\
1\end{array}$ \\
\hline \multirow{2}{*}{ TOPICALISED SUBJECT } & $\begin{array}{l}\text { XP-ka } \\
\text { subject-fa }\end{array}$ & $>$ subject-fa & 1 \\
& & $>$ XP-ka & 18 \\
\hline
\end{tabular}

The data in Tab. 2, stemming from Nomura (1993a, b), motivate a generalisation according to which $k a$-marked constituents generally follow $f a$-marked topics and precede genitive subjects, which we adopt from Aldridge (2009) and provide in (5).

(5) NOMURA'S GENERALISATION (Aldridge, 2009: 557):

XP-fa ....YP-ka ....DP-GEN ...V-ADN

Watanabe (2002) thus proposed, and reiterated in Watanabe (2005), an analysis of high $w$ h-movement to [Spec, FocP], where Foc may well stand for our $\kappa$ head, where he located the $\kappa$ head in the left-peripheral position of the clause. Given the evidence in Tab. 2, the partial syntax of OJ CP is the one in (12). In line with Whitman (2001), and indeed Kayne (1994: 143, fn. 3), we take the OJ genitive no/ga markers to be exponents of $\mathrm{T}^{0}$ and the topic marker $f a$ to be the realisation of Top ${ }^{0}$.

(6) Clausal left periphery in OJ:

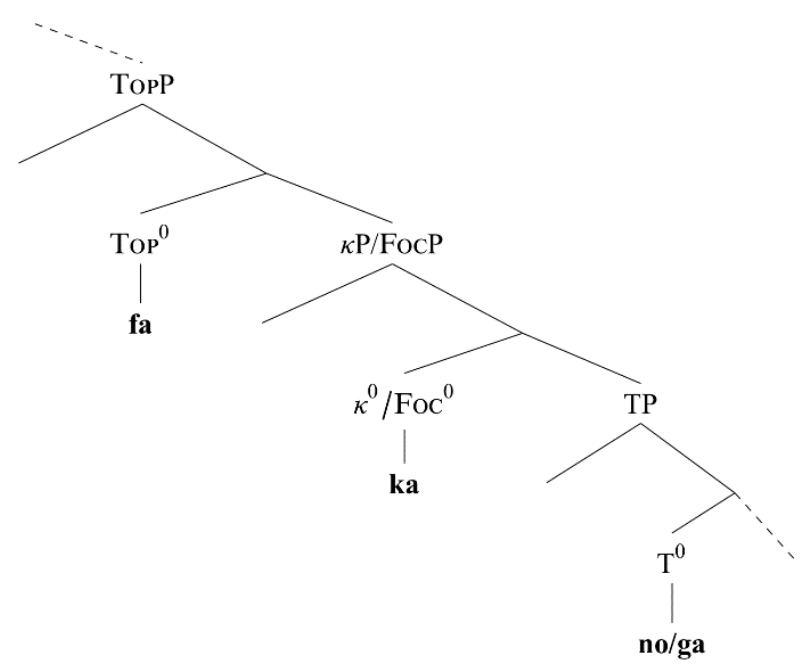


Instead of an analysis according to which the wh-terms target a high focus position above the TP (6) as originally proposed by Watanabe (2002), Aldridge (2009) refines the analysis and proposes to treat the wh-movement as targeting a low focus position, as indicated in (7b), instead of a high focus position (7a). The Foc head in (7a) and (7b) corresponds to our $\kappa$ label.
a. HIGH FOCUS MOVEMENT
[TopP XP Top [FocP $\mathrm{YP}_{w h}$ Foc $\left.\left.\left[\mathrm{TP} \mathrm{DP}_{\mathrm{GEN}} \ldots\right]\right]\right]$
b. LOW FOCUS MOVEMENT
$\left[\right.$ TopP XP Top $\left[\mathrm{TP}_{\mathrm{DP}} \mathrm{DP}_{\mathrm{GEN}}\left[\mathrm{FocP} \mathrm{YP}_{w h}\right.\right.$ Foc $\left.\left.\left[{ }^{\mathrm{PP}} \mathrm{DP}_{\mathrm{GEN}} \ldots\right]\right]\right]$

Aldridge (2009: 551) shows that genitive subjects, unlike nominative subjects residing in [Spec, TP], are rather better analysed as residing in their base-generated position in [Spec, $v \mathrm{P}$ ], which additionally allows for a TP-internal landing site for $w h$ movement. Aldridge (2009: sec. 3) additionally shows that, other than the topic-marked $(f a)$, syntactic material may precede the wh-elements, which a high-movement analysis (Watanabe 2002, 2005) does not predict and which, in fact, severley compromises the analysis according to which wh-movement targets a high left-peripheral position. Consider (8) taken from Aldridge (2009: 555).

$\begin{array}{llll}\text { 保登等芸須 } & \text { [都奇 多都 麻泥爾] 奈仁加 } & \text { 吉奈可奴 } \\ \text { pototogisu } & \text { [tukwi tatu made-ni] nani ka } & \text { ki-naka-nu } \\ \text { cuckoo.NOM } & \text { [moon rise before-DAT] why } \boldsymbol{~} & \text { come-sing-NEG }\end{array}$

'Why does the cuckoo not come to sing [before the moon rises]?'

(MYS 17.3983, 11. 3-5; from Aldridge 2009: 555)

Even scrambled objects, assumed to target the edge of TP (McGinnis 1999; Miyagawa 2001, 2003, 2005) appear in a position preceding the $\kappa$-wh-phrase, as Aldridge further demonstrates. In (9), the wh-phrase is shown to follow both the scrambled object, residing in [Spec,TP], and an adverb located in a position higher than the high wh-movement analysis would predict.

（9）都袮斯良農 道 乃 長手 袁 久礼久礼等 伊可 [tune sira-nu miti no nagate] wo kurekure-to ika-ni [normally know-NEG road GEN journey]ACC in-dark how-DAT

$\begin{array}{ll}\text { 可 由迦牟 } \\ \text { ka yuka-mu } \\ \text { к } & \text { go-SUPP }\end{array}$

'How should I proceed in the dark on a journey on a road I normally do not know?'

(MYS 5.888a, 11. 1-4; from Aldridge 2009: 555) 
Regarding the question that intrigues us most here, namely the synchronic and diachronic status of morphosyntactically encoded interrogativity, Aldridge (2009: 561) recognises that the $\kappa$ particle had no interrogative force whatsoever, since (semantically) its function seems to have operated a focus-sensitivity role alone and (syntactically) its position, as Aldridge (2009) convincingly shows, is far lower for it to attain interrogative scope. Instead, she proposes that the mechanism of interrogative scope-taking is unselective binding for, at least, two reasons: (a) $w h$-items can appear inside islands, as Whitman (2001) first observed; and (b) $w h$-words function as indefinite variables. ${ }^{4}$

What we do know, and demonstrate below, is that $\kappa$ developed its interrogative semantics and high syntactic position in the later periods, namely after the 14th century. Takamiya (2005) first observed the constant diachronic rise of the (indirectly) interrogative function of the $k a$ particle, which we list in Tab. 3 and plot in Fig. 1. See also Kinuhata and Iwata (2009) for a diachronic analysis.

Table 3: Diachrony of questions with $k a$ (か) in Japanese (Takamiya, 2005).

\begin{tabular}{lccccccc}
\hline century & 14 th & 15 th & 17 th & 18 th & $18-20$ th & 19 th & 20 th \\
\hline \# of tokens & 1 & 9 & 31 & 23 & 34 & 40 & 121 \\
\hline
\end{tabular}

Figure 1: Diachrony of $k a$-marked indirect questions in Japanese

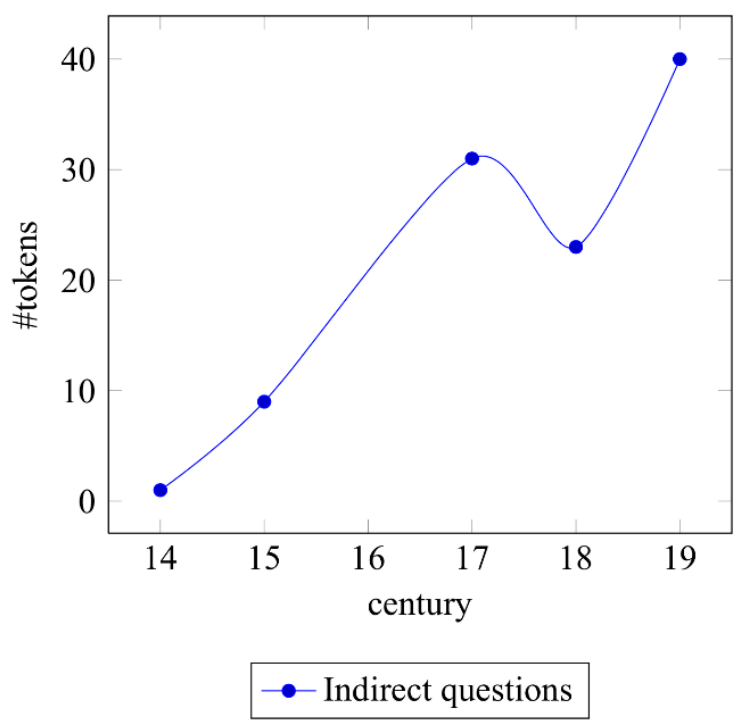

Also note that both $m o(\mu)$, another prominent OJ particle, and $k a(\kappa)$ may co-occur simultaneously, which obtains a kakarimusubi-like construction featuring both an

${ }^{4}$ A variable treatment of $w h$-terms in OJ is also defended in Mitrović (2014: ch. 5). 
interrogative and a focus meaning. Since $\kappa$ did not encode for interrogativity, we assume this is done by a silent Q-operator. The following two examples show the co-occurrence of mo $(\mu)$ and $\mathrm{ka}(\kappa)$ particles.
何物鴨
御狩
人之
折而
将挿頭
Nani-wo-ka-mo mikari=no fito-no ori-te kazasa-mu
what-ACC- $\boldsymbol{\kappa}+\boldsymbol{\mu}$ hunt-GEN person-GEN pick-CONJ wear.on.hair-MOD.ADNOM
'What should the hunters pick and wear on their hair?'

(MSY 10.1974, 11. 3-5; Aldridge 2009: 550)

$\begin{array}{llllll}\text { (11) 伊可爾 } & \text { 安良武 } & \text { 日能 } & \text { 等伎爾 可母 } & \text { 許 } \\ \text { ika-ni } & \text { ara-mu } & \text { pi-no } & \text { toki-ni } & \text { ka-mo } & \text { k } \\ \text { how-DAT } & \text { be.MOD } & \text { day-GEN } & \text { time-DAT }+\boldsymbol{\mu} & \text { vor } \\ & \text { 比等能 } & \text { 比射乃 } & \text { 倍 } & \text { 和我 } & \text { 麻久良可武 } \\ \text { pito-no } & \text { piza-no } & \text { pe } & \text { wa-ga } & \text { makuraka-mu } \\ \text { person.GEN } & \text { knee.GEN } & \text { on } & \text { 1s-NOM } & \text { rest.head-SUPP }\end{array}$

'On the day which will be like what will I rest my head on the knee of someone who understands me?'

(MYS5.810; Aldridge 2009: 560)

We therefore slightly rearticulate Nomura's generalisation so as to include the particle $\mu(\mathrm{mo})$ as being in a fixed position. (See Mitrović 2014 for details.)

(12) Clausal left periphery in OJ (articulated):

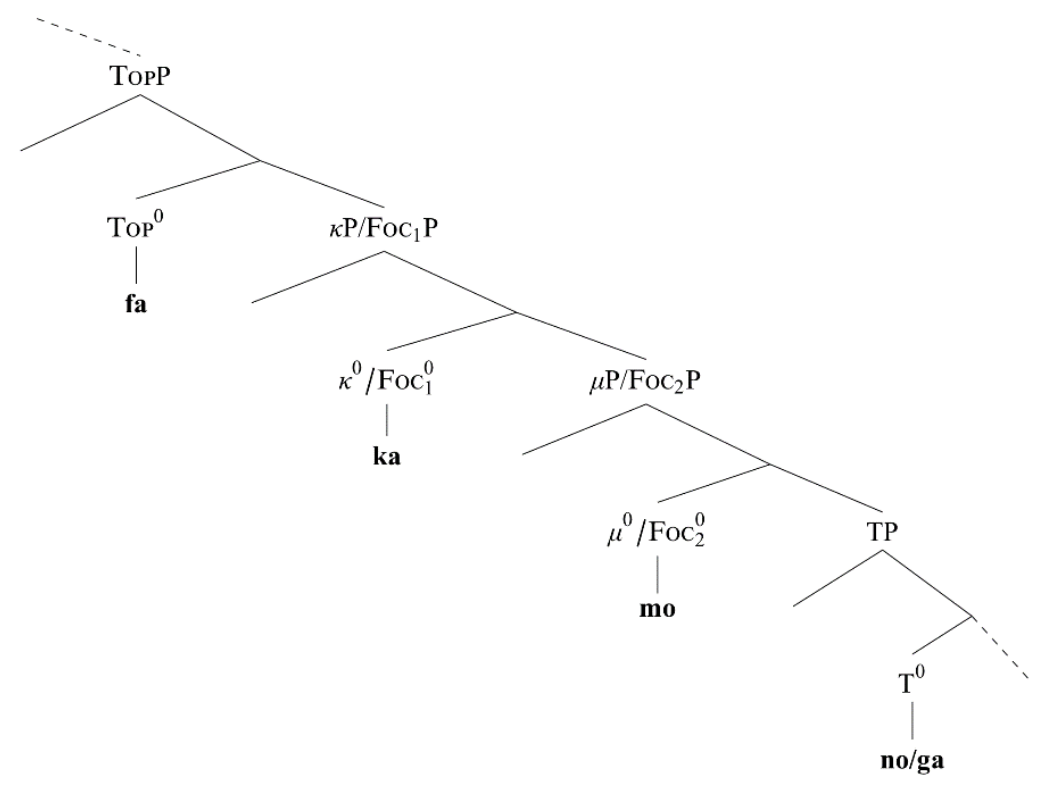


In Tab. 4, we list occurrences and types of particle composites in OJ as found in MYS. The fact that $m o$ and $k a$ occur in rather fixed positions confirms our conjecture of rearticulating Nomura's generalisation as stated in (12).

Table 4: The relative order of ka-phrases in MYS ( $\mathrm{p}<0.005)$ as per Nomura $(1993 \mathrm{~b}$, a) and Wrona (2007).

\begin{tabular}{ll}
\hline particle sequence & \# of tokens \\
\hline ka mo ka mo & 2 \\
\hline mo ka mo ka & 0 \\
\hline mo ka mo & 9 \\
\hline mo ka & 60 \\
\hline mo ga & 1 \\
\hline ga mo & 3 \\
\hline ka mo & 154 \\
\hline ga mo ga & 0 \\
\hline ga mo ga mo & 0 \\
\hline mo ga mo ga & 0 \\
\hline
\end{tabular}

Given Aldridge's (2009) evidence of the low position of $\mathrm{kP}$, we simply relocate the $\kappa \mathrm{P}-\mu \mathrm{P}$ phrase couple to a lower position, along the lines of Aldridge's (2009) original proposal.

$$
\begin{aligned}
& \text { LOW FOCUS MOVEMENT (rearticulated) }
\end{aligned}
$$

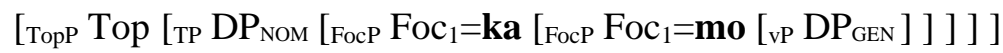

In CJ, the ka-mo particle composite was lost, as Frellesvig (2010: 241) convincingly shows, which parallels our diachronic analysis, stated in (14), according to which $\kappa$ underwent eventual structural reanalysis from a lower pre-verbal TP-internal position to a higher CP-internal position. 
(14)
a. $\quad \mathrm{OJ} / \mathrm{CJ}$ :
$\gg$
b. post-CJ/MdJ

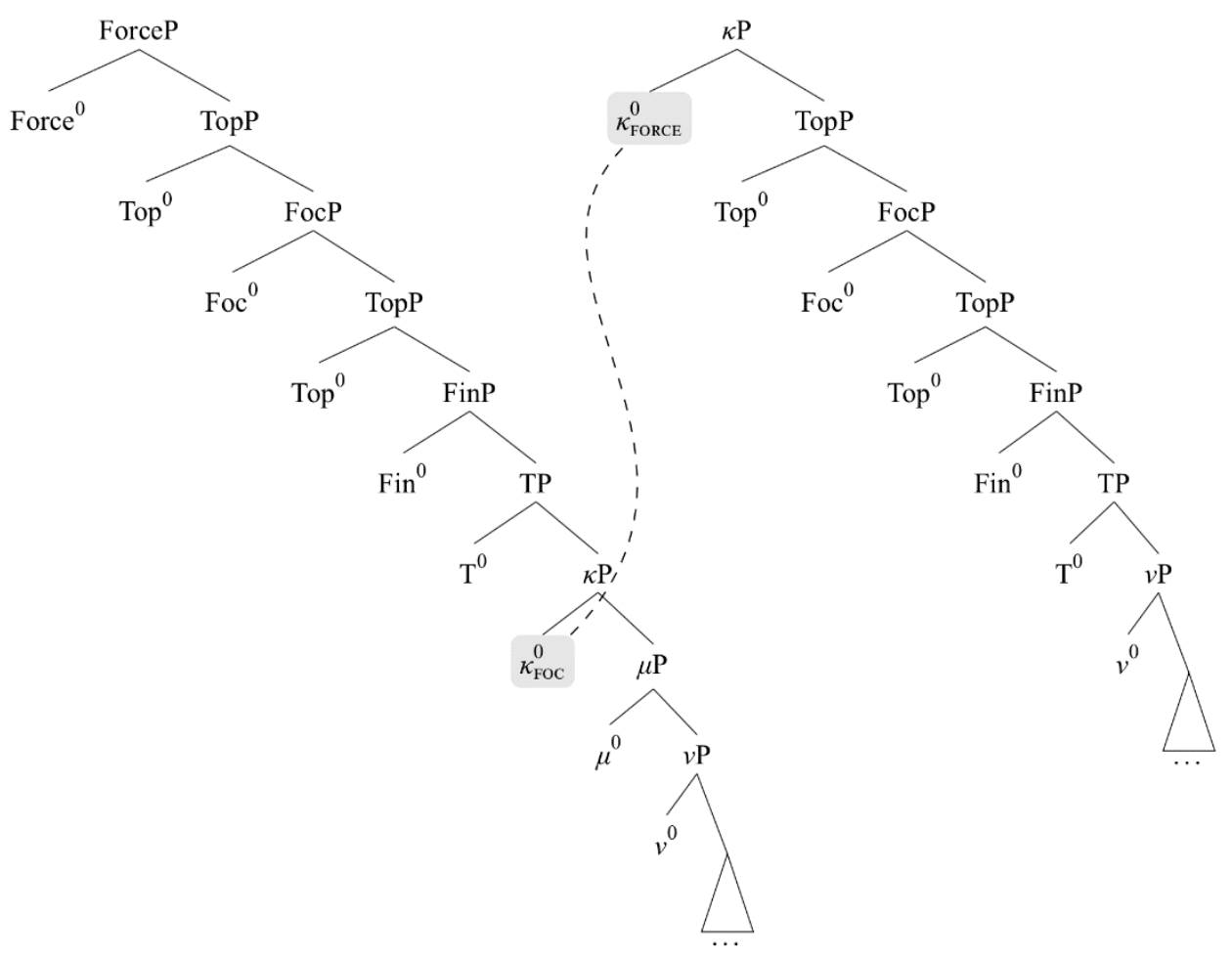

Semantically, the change is from a focus-sensitive to an interrogative operator. Conceptually, both focus and interrogative constructions share an alternative-semantic core in that they both raise alternatives. Technically, the focus hosts of OJ/CJ $\kappa$ are generally DPs - predominantly, wh-words, as we have been exploring. The interrogative $\kappa$ in the post-classical period is confined to propositional hosts. While focus-alternatives are type-ambivalent and contextually determined, polar question alternatives are typefixed, i.e. confined to propositional types $\langle s, t\rangle$ and inherently binary.

In the next section, we motivate a syntactic structure for KM along with a compositional semantics.

\section{A compositional analysis of kakarimusubi}

In this section, we review and adopt the recent proposal by Chierchia and Caponigro (2013) according to which free relatives (FRs) are derived from questions (Qs). We show that this account lends itself to an analysis of KM, which we have already overviewed. Before we move onto the two points of interest and application, let us first review Chierchia and Caponigro's (2013) derivation. 


\subsection{Setting up the formal system: questions and free relatives}

The idea that relative and question expressions share a interrogative core is put forth up by Chierchia and Caponigro (2013), whom we follow so as to derive the $\kappa$-marked KM.

Chierchia and Caponigro (2013) adopt a loose variant of Cecchetto and Donati's (2010) approach to free relatives and labelling, according to which interrogative and relative constructions share a common syntax, modulo the label of the root, on which the interpretation hinges. Take (15), taken from Cecchetto and Donati (2010), where the labelling algorithm at the root of the tree cannot readily determine a label $(\Lambda)$ for the structure since the tree is essentially a set containing two subsetssets: $\left\{\Lambda:\left\{\Lambda_{1: D}\right.\right.$ what $\}$ (the wh-term in $[\mathrm{Spec}, \mathrm{CP}]$ ) and $\left.\left\{\Lambda_{\mathrm{C}} \mathrm{CP}\right\}\right\}$ (the $\mathrm{CP}$ without its left edge).

Cecchetto and Donati's (2010) labellability of Qs vs. FRs:

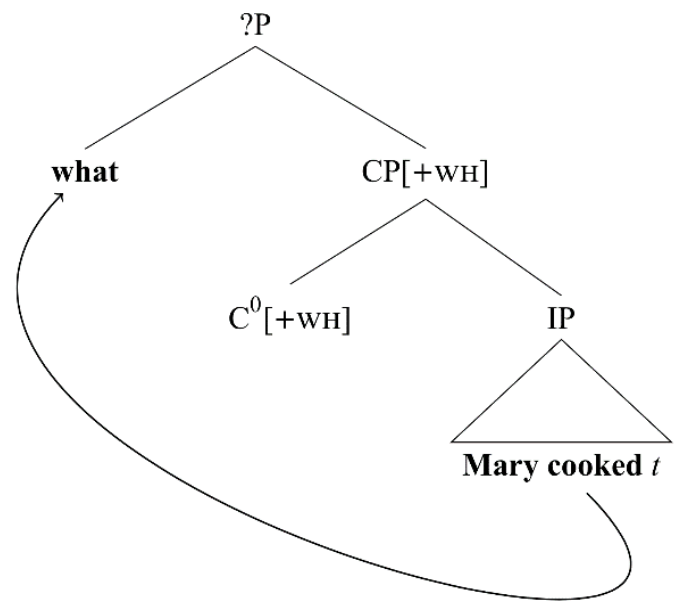

There is a theoretically presupposed idea in treating the Q/FR distinction, namely that they share a derivationally identical structure, modulo the final label, which is determined structure-externally, i.e. c-selectionally. In broad terms, if a head $\alpha$ merges above and combines with ?P in (15), ?P projects/labels as [C] if $\alpha$ subcategorises for [uC]; alternatively, if $\alpha$ subcategorises for [uD], ?P projects the [D] label as provided by what in $[\mathrm{Spec}, ? \mathrm{P}] .^{5}$

Chierchia and Caponigro (2013) thus build on this idea that relatives, such as Mary ate what John cooked, are structurally-and thus interpretationally-embedded interrogatives. Note that this departs from traditional analyses, both syntactically, where relativisation is completely independent from interrogativity, as well as semantically,

5 The subcategorisation is notated using $u$ ninterpretable categorial features $([\mathrm{uC}])$, as per minimalist assumptions (Chomsky 1995) briefly laid out in the previous section. 
where the traditional view maintains that clauses with $w h$-terms are traditionally seen as property- or set-denoting $\lambda$-abstracts, as per Groenendijk and Stokhof (1983) and that there exist two distinct semantic shift of the (presumably homophonous) denotation of the $w$ h-term. One type shift_-TS1 in (16) - lifts the $w h$-term to the level of propositions, yielding a question. The other type shifting operation-TS2 in (16) - lowers the type of the $w$-term to an $e$-type, presumably via an 1 -operator (Partee 1987, inter. al.), yielding a FR. The following scheme in (16), taken from Chierchia and Caponigro (2013: 2, ex. 4 ), shows the traditional semantic split in the denotation of $w h$-terms.

(16) The traditional approach to the denotation of wh-abstracts:

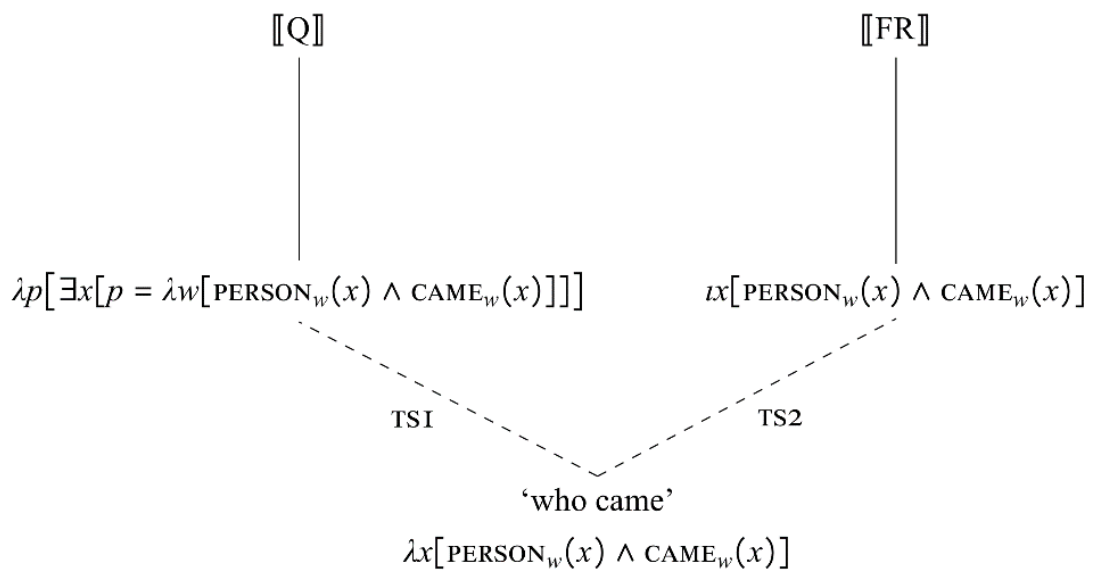

We will follow their work and apply it to the Japonic construction of KM. To do so, we expand the syntactic inventory of Chierchia and Caponigro's (2013) theory and attempt a syntactic/semantic derivation and interpretation of the of partially interrogative focus in pre-modern Japonic.

Before proceeding to the two sets of data and analyses, let us briefly expound on Chierchia and Caponigro's (2013) theory so as to understand the core motivations and technical building blocks of their system.

Empirically, Chierchia and Caponigro (2013) draw their motivation from an empirical generalisation, dubbed Caponigro's generalisation, taken from Chierchia and Caponigro (2013: 2, ex. 3)

CAPONIGRO'S GENERALISATION (Caponigro 2003, 2004)

If a language uses the wh-strategy to form both Qs and FRs, the wh-words found in FRs are always a subset of those found in Qs. Never the other way around. Never some other arbitrary relation between the two sets of wh-words. 
Let us now turn to Chierchia and Caponigro's (2013) derivation of questions, which they build from a list of lexical entries in (18). The composition and interpretation is follows standard assumptions, modulo the excorporation of the question-forming head $\left(\mathrm{C}^{0}{ }_{[+\mathrm{Q}]}\right)$ from a clause head-complex. With respect to this mechanical move, Chierchia and Caponigro's (2013) adopt Shimada's (2007) head-unfolding model, which we will briefly introduce below. While $\mathrm{C}^{0}{ }_{[+\mathrm{Q}]}$ creates a protoquestion, as assumed by Kartunnen (1977), and many others subsequently, it is simultaneously the element that derives the actual interrogative meaning. The common assumption is that $\mathrm{C}^{0}{ }_{[+\mathrm{Q}]}$ cannot be interpreted in situ and so it must be merged at the root of the CP.

The derivation and interpretation of FR relies on the same building blocks, namely the excorporation of an operator from within the clause-head complex. The derivational difference between Qs and FRs, as we have observed in (15) on independent (labelling) grounds, following Cecchetto and Donati (2010), lies in the label of the CP (or ?P). Under Shimada's (2007) assumptions, the label is not determined CP-externally but rather CP-internally, by virtue of head-unfolding. For Chierchia and Caponigro (2013), the difference between Qs and FRs lies in the probing mechanism, i.e. whether it is a Qforming or a FR-forming operator that excorporates from the clause-head complex. In their analysis of FRs, the excorporating head is a nominal operator, which Chierchia and Caponigro (2013) dub $\mathrm{D}_{\mathrm{REL}}$.

In the system we are adopting, $\mathrm{D}_{\mathrm{REL}}$ functions as a nominal operator that extracts the Topical Property (TOPR) out a clause. TP is, in turn, defined as a singleton property of a question. This latter definition of TP, which underlies the notion of $\mathrm{D}_{\mathrm{REL}}$, thus relies on answerhood conditions, for which Chierchia and Caponigro (2013) adopt a Dayal-style Ans(werhood) operator. In (18), we provide the definitions of the three interdependent operators. Additionally definable is the short-asnwerhood operator $\left(\mathrm{Ans}^{\mathrm{S}}\right)$, since all questions have short answers, which Chierchia and Caponigro (2013) take to be the very extractable property that $\mathrm{D}_{\mathrm{REL}}$ delivers. Hence, $\mathrm{D}_{\mathrm{REL}}$ denotes a (or rather the) short answer to a question (18d-i) or a type-lifted variant thereof in form of a generalised quantifier (GQ), as per (18d-ii).

$$
\begin{aligned}
& \text { a. } \llbracket A n s \rrbracket^{\mathrm{w}}(Q)=1 p \in Q\left[p_{w} \wedge \forall q \in Q\left[q_{w} \rightarrow p \subset q\right]\right] \\
& \text { b. } \quad \llbracket A \operatorname{Ans}^{\mathrm{S}} \rrbracket^{w}(Q)=1 x\left[[\mathrm{TOPR}]_{w}(x)\right] \\
& \text { c. i. } \quad \text { iTOPR } \rrbracket=\lambda P_{\langle s,\langle e, t\rangle\rangle} \forall w \forall x\left[P_{w}(x) \leftrightarrow \lambda w^{\prime}\left[P_{w^{\prime}}(x)=\operatorname{Ans}_{w}(Q)\right]\right] \\
& \text { ii. } \quad \llbracket T O P R \rrbracket(Q)={ }_{1} P \forall w \forall x\left[P_{w}(x) \leftrightarrow \lambda w^{\prime}\left[P_{w},(x)=\operatorname{Ans}_{w}(Q)\right]\right] \\
& \text { d. } \quad \text { i. } \quad \llbracket \mathrm{D}_{\mathrm{REL}} \rrbracket^{w}(Q)=\llbracket \mathrm{Ans}^{\mathrm{S}} \rrbracket^{w}(Q) \\
& \text { ii. } \quad \llbracket \mathrm{D}_{\mathrm{REL}} \rrbracket^{w}(Q)=\lambda P \exists x\left[[\operatorname{TOPR}(Q)]_{w} \wedge P_{w}(x)\right]
\end{aligned}
$$

For (18d-ii), however, the definition of Ans as it currently stands in (18c-i) will not suffice, hence a type-lowered variant of (18c-i) is given in (18c-ii). While Chierchia and Caponigro (2013) do not discuss the syntactic nature of the input to semantic interpretation, which obtains the two differential LFs for questions and free relatives, we now turn to the syntactic input of such LFs. 
While the syntactic origin of $\mathrm{D}_{(\mathrm{REL})}$ as head-sister of $\mathrm{C}^{0}$ is stipulation in Chierchia and Caponigro's (2013) system, we reconcile this by adopting an articulated structure of $\mathrm{C}^{0}$. We do so by adopting Rizzi's (1997) left-peripheral microscopy of the clause. Recall from (18) that both the Ans ${ }^{\mathrm{S}}$ and the $\mathrm{D}_{\mathrm{REL}}$ operators ontologically rest on and are built from the TOPR element.

It is my proposal here to locate the structural locus of TOPR in one of the two of Rizzi's (1997) Topic heads. I propose we treat the C-complex, the structure of which, and indeed the movement from which, yields the differential interpretation, in the following way. Assuming a rich micro-structure of the C head, following Rizzi (1997), we locate the different heads within the left periphery and assign them the semantic potential to yield as calculated meanings the entires in (18).

Before implementing the proposal, we additionally extend our proposal by adopting Shimada's (2007) model of head movement. A phrase-structural spine, like the one of a $\mathrm{CP}$ which can be represented as in (19a), is traditionally built in a bottom-to-top fashion. Shimada (2007) convincingly argues for the derivational procedure that is primarily the inverse of (19a) and 'unfolds' to a structure like the one in (19a) through successive excorporation (19b). The specific steps of the 'unfolding' steps are given in (19b-i) through (19b-iii). ${ }^{6}$

We do not go into any greater detail of Shimada's (2007) proposal; the reader is instead referred to the original work (Shimada 2007), or its application in Chierchia \& Caponigro (2013) and Mitrović (2014: ch. 2).

$$
\begin{aligned}
& \text { a. [Cе } \mathrm{C}[\mathrm{TP} \mathrm{T}[\mathrm{vP} \mathrm{V}[\mathrm{vP} \mathrm{V}]]]] \\
& \text { b. [v V [v v [ } \\
& \text { i. } \left.\left.\left[\mathrm{v} \mathrm{V}\left[\mathrm{v} \mathrm{v}\left[\mathrm{T}_{\mathrm{T}} \mathrm{T} \mathrm{C} \mathrm{C}\right]\right]\right]\right]>\left[{ }_{\mathrm{v}} \mathrm{v}\left[\mathrm{T}_{\mathrm{T}} \mathrm{T}[\mathrm{C} \mathrm{C}]\right]\right]\left[\mathrm{v} \mathrm{V} \mathrm{t}{ }_{\mathrm{v}}{ }^{1}\right]\right]
\end{aligned}
$$

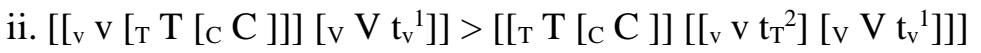

$$
\begin{aligned}
& \text { iii. }\left[\left[{ }_{\mathrm{T}} \mathrm{T}\left[{ }_{\mathrm{C}} \mathrm{C}\right]\right]\left[\left[\mathrm{v}_{\mathrm{v}} \mathrm{t}_{\mathrm{T}}{ }^{2}\right]\left[\mathrm{v} \mathrm{V} \mathrm{t}_{\mathrm{v}}{ }^{1}\right]\right]\right]>\left[[\mathrm{C} \mathbf{C}]\left[\left[\mathrm{T}_{\mathrm{T}} \mathbf{T} \mathrm{t}_{\mathrm{C}}{ }^{3}\right]\left[\left[\mathrm{v}^{\mathrm{v}} \mathrm{t}_{\mathrm{T}}{ }^{2}\right]\left[\mathrm{v} \mathbf{V ~ t}_{\mathrm{v}}{ }^{1}\right]\right]\right]\right]
\end{aligned}
$$

We take the same excorporational procedure to extend to the articulated clausal projection, as per Rizzi's original fine-grained view of the left periphery (LP), which we state in original in (20a). Upon 'head unfolding' (20b), the LP takes the shape of (20a). Under this analysis (extended to the clausal LP), another options makes itself available technically, i.e, the availability of inconsistent excorporation of the last head complex containing $\left\{\Lambda\right.$ :Top $\operatorname{Top}^{0}$, Force $\left.^{0}\right\}$.

\footnotetext{
${ }^{6}$ We subscript traces $(t)$ of movement with numerals which should be read procedurally as denoting succesccive steps of excorporation. The terminal heads in (19b-iii) are given in bold for clarity.
} 
(20)

a. Rizzi’s (1997) take on the finegrained LP:

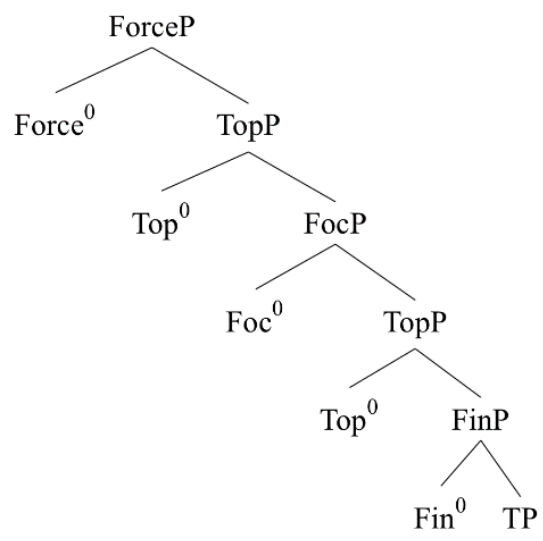

b. Rizzi’s (1997) LP derived in line with imada (2007):

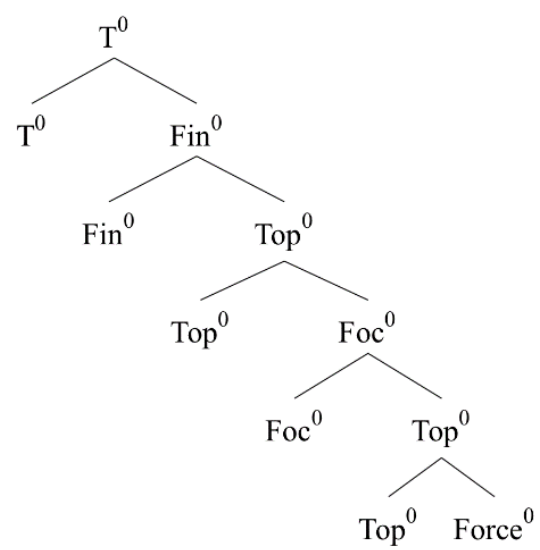

It seems reasonable to assume that while the full LP head-set unfolds, in line with Shimada's (2007) derivational assumptions, not all LP heads may be interpretationally active. Under the assumption that the richness of the LP is universally present, in one form or another, then conceptually, an inactive head may simply make no contribution. The inactivity can be stated in terms of F-valuation: non-locally through long-distance probing of a LP head within the clausal interior (e.g. in situ focus association, or topic); or, locally via [EPP]-like driven movement to specifiers of respective LP heads. If a LP head does not enter into any checking relation with an element within the clausal interior, a head can be said to be inactive. Semantically, inactive heads are ignored at LF, or are assigned identity function meaning so as to not make any meaningful (or at least pragmatically enriching) contribution. For convenience, we ignore the specifier slots and the recursivity notation of Topic projections that Rizzi (1997) states, and translate IP into TP since nothing will hinge on these modifications.

Semantically, we propose that the TOPR is part of the meaning of the high Topic head, i.e. $\llbracket T O P R \rrbracket \in \llbracket T_{0}^{0} \rrbracket$. The (potentially) non-exhaustive meaning of the Top head is taken to be $\mathrm{D}_{\mathrm{REL}}$. The reasons for height preference will become clear below.

Derivationally, we are concerned with the unfolding of heads up to the last point, when the C-head complex contains the high Topic head and the Force head ( $\left\{\right.$ :Top Top ${ }^{0}$, Force $\left.{ }^{0}\right\}$, cf. 20b), the former encoding for topicality (TOPR, under our assumption), the latter for interrogativity.

Given the need for the protoquestion (PQ) operator for the calculation of of both $\mathrm{Q}$ and FR meanings, itself of type $\langle\langle s, t\rangle t\rangle$, we stipulate its (syntactically silent) placement 
in the LP, such that the following structural hierachy obtains: $\left.\left.\left.\mathrm{Force}^{0}\right\rangle \mathrm{Top}^{0}\right\rangle \mathrm{PQ}\right\rangle \mathrm{Foc}^{0} .{ }^{7}$ Given the type mismatch of the head-complex containing $\left\{\operatorname{Top}^{0}\right.$, Force $\left.^{0}\right\}$, one of the heads moves out of the complex and is interpreted at the root, as per (21).
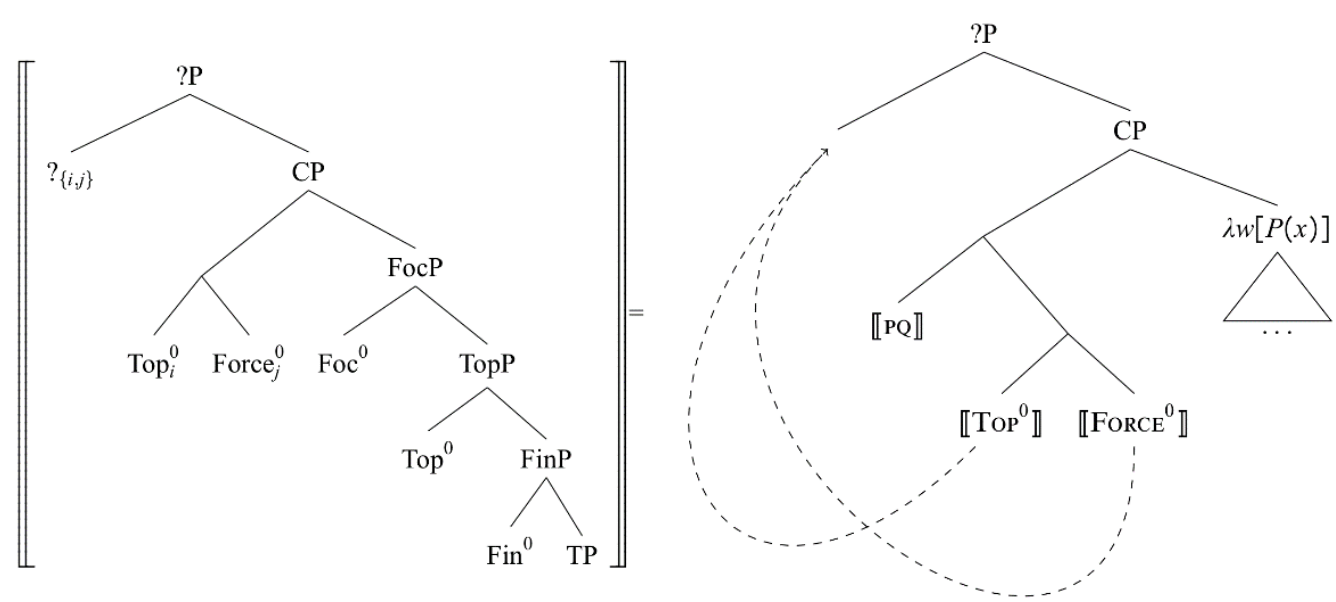

The head adjacency follows from Shimada's (2007) model applied to Rizzi's (1997) dissection of the clause. We gain two advantages: firstly, the syntactic ontology of DREL is no longer a stipulation as we are identifying it as Top ${ }^{0}$. Secondly, Rizzi's (1997) LP provides a head-adjacent relation between (the high) Top and Force by virtue of the head unfolding derivational procedure of Shimada (2007). This way, we maintain, in slightly more syntactically technical terms, Chierchia and Caponigro's (2013) assumption that selection and excorporation of the second operator - $\mathrm{C}$ vs. DREL - is in fact a matter of Agree relation.

\subsection{Interpreting kakarimusubi from Focus and FR}

We return to the case in hand, namely the derivation and compositonal interpretation of kakarimusubi, the data of which we briefly restate below in (22) from (1).

$\begin{array}{llll}\text { 敵見有 } & \text { 虎 } & \text { 可 } & \text { 吼登 } \\ \text { atami-taru } & \text { twora } & \mathbf{k a} & \text { poyu-ru } \\ \text { iritated.STAT } & \text { tiger } & \mathbf{\kappa} & \text { roar-ADN }\end{array}$

'Is it [an irritated tiger] ${ }^{\mathrm{F}}$ that is roaring?' (MYS 2.199)

\footnotetext{
${ }^{7}$ Although this is a stipulation, all classical semantic theories of the composition of questions assume it implicitly, hence the syntactic nature of PQ does not constitute any controversies here.
} 
Our analysis of kakarimusubi will rely on the technical foundations of Chierchia and Caponigro (2013) and the results of Aldridge (2009).

We take the musubi component of the construction, i.e. the presupposed content morphosyntactically marked with adnominal morphology, i.e. -ru in (22), to share the FR syntax and semantics as we have developed it. The kakari component results from movement of a segment contained within the $v \mathrm{P}$ to $[\mathrm{Spec}, \kappa \mathrm{P}]$, itself a slot in the left periphery of the $v \mathrm{P}$, as Aldridge (2009) has independently motivated.

Under the present analysis, the adnominal marker is an exponent of the (semantically nominal) $\mathrm{Top}^{0}$, hence movement of the remnant $v \mathrm{P}$ material-poyu'roar(ing)' in (22) — to its specifier position results in pronunciation of the specifier and head as an adnominally marked verbal element $(p o y u+r u)$. The focus-associating $\kappa-$ marked DP then remnant-moves to the root of the clause.

We further adopt Whitman's (1997) analysis of KM as a cleft-like construction. Under a cleft-approach of Whitman (1997), the presupposition of the musubi constituent comes for free. (Delin, 1992) Given the biclausal nature of clefts, we take the $\kappa P$ subsequently to move successive cyclically across the clause boundary into the higher $\mathrm{CP}$, which also contributes the interrogative meaning.

The derivation of our exemplar case in (22) is therefore the one given in (23). For simplicity, we ignore the copies from the internal structure of the moved material. We also make use of dashed nodes to ignore the intermediate projections that are not necessarily relevant to the derivation. Terminals on sites of pronunciation are marked in bold.

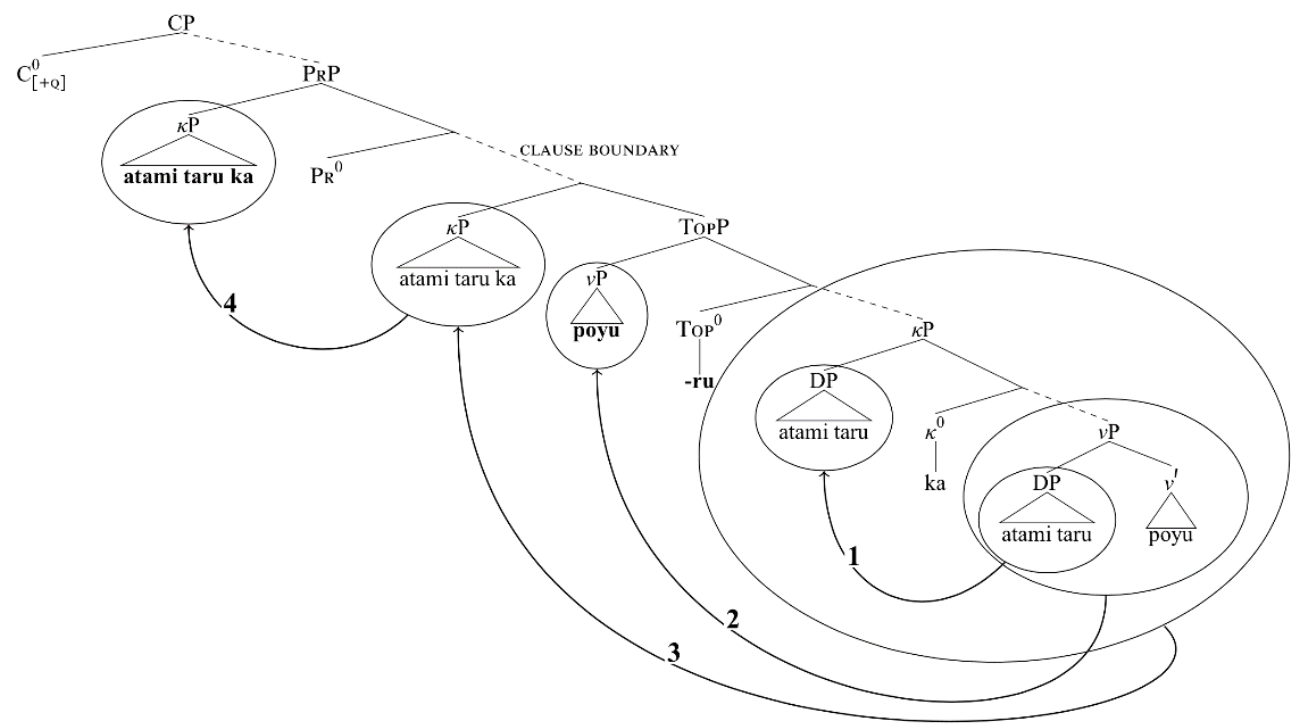


Under this analysis, the interpretation of the lower clause, containing (and denoting) the musubi presuppositional component of the proposition is the same as the interpretation of a FR under Chierchia and Caponigro's (2013) analysis. The association with focus takes place in the higher clause, which also, at least in the case of (23), encodes the interrogative meaning.

The interpretation of the lower clause $\left(\mathrm{CP}_{\text {low }}\right)$, turned into a DP along the lines explored above, is thus a presuppositional FR, while the higher CP involves a $\kappa$-headed focus construction and a question, as shown in (24). ${ }^{8}$

$$
\begin{array}{ll}
\text { a. } & \llbracket \mathrm{CP}_{l o w} \rrbracket=\lambda P \exists x\left[x=1 x\left[\operatorname{ROARED}_{w}(x)\right] \wedge P_{w}(x)\right] \\
\text { b. } & \llbracket \mathrm{CP}_{h i g h} \backslash \mathrm{C}_{[+\mathrm{Q}]} \rrbracket=\mathrm{EXH}_{[\mathrm{D}]}(p)=p \wedge \forall q \in \operatorname{Alt}(p)[[p \vdash q] \rightarrow \neg q], \\
& \text { where } p=\exists x\left[x=1 x\left[\operatorname{ROARED}_{w}(x)\right] \wedge \operatorname{IRITATED}-\operatorname{TiGER}_{w}(x)\right] \\
\text { c. } & \llbracket \mathrm{CP}_{h i g h:[+\mathrm{Q}] \rrbracket} \rrbracket \lambda q[\mathrm{EXH}(p)=q \vee \operatorname{EXH}(p)=\neg q], \\
& \text { where } p=\lambda w \exists x\left[x=1 x\left[\operatorname{ROARED}_{w}(x)\right] \wedge \operatorname{IRITATED}-\operatorname{TiGER}_{w}(x)\right]
\end{array}
$$

Recall also the fact that KM was lost in the post-classical period, when the interrogative function of the $\kappa$-particle enters the language. This also shows the diachronic interlock between interrogative and cleft-like focus constructions involving FRs in an elegantly compatible way. We leave, however, the details of the diachronic procedures which gave rise to grammaticalised interrogativity of $k a$ for further research.

\section{Conclusion}

This paper has entertained a novel analysis of KM. We first reviewed the synchronic status of its syntax, noting the details of its diachronic decline from 12th through 17th centuries. (Watanabe 2002). Following Aldridge (2009), int. al., we have identified a sub-clausal and pre-verbal syntactic position for the focus-sensitive $k a$-particle. In Section 3, we have attempted a mapping from syntax onto compositional semantics so as to derive the compositional interpretation of the KM. Having adopted Chierchia \& Caponigro's (2013) analysis of FRs as embedded interrogatives, we proposed that the adnominality marking on the musubi presuppositional component has its exponential locus in the higher Top ${ }^{0}$ nucleus of Rizzi's (1997) left-periphery system.

\section{Primary source}

MYS Man’yōshū. (万葉集) ca. 759 AD. Text edition as per Frellesvig et al. (2014).

\footnotetext{
${ }^{8}$ The assumption underlying the computation of focus semantics in (24) is the inherently exhaustive constribution of Focus (derived by the EXH-operator). For details on the EXH-based account, see Chierchia (2013).
} 


\section{References}

Aldridge, E. (2009). Short wh-movement in Old Japanese. In Iwasaki, S., Hoji, H., Clancy, P., and Sohn, S., editors, Japanese/Korean Linguistics, volume 17, pages 549-563. Stanford, CA: CSLI.

Caponigro, I. (2003). Free Not to Ask: On the Semantics of Free Relatives and Wh-Words Crosslinguistically. $\mathrm{PhD}$ thesis, UCLA.

Caponigro, I. (2004). The semantic contribution of $W h$-words and type shifts: Evidence from free relatives crosslinguistically. In Young, R. B., editor, Proceedings of SALT 14, pages 38-55. Ithaca, NY: CLC Pub- lications, Cornell University.

Cecchetto, C. and Donati, C. (2010). On labeling: Principle C and head movement. Syntax, 13(3):241-278.

Chierchia, G. (2013). Logic in Grammar. Oxford: Oxford University Press.

Chierchia, G. and Caponigro, I. (2013). Questions on questions and free relatives. Paper presented at Sinn und Bedeutung 18. Handout accessible at <http://scholar.harvard.edu/files/chierchia/files/frs_and_qs_iii_--.pdf.>

Chomsky, N. (1995). The Minimalist Program. Cambridge, MA: MIT Press.

Dayal, V. (1996). Locality in Wh-Quantification: Questions and Relative Clauses in Hindi. Dordrecht, Kluwer.

Delin, J. (1992). Properties of it-cleft presupposition. Journal of Semantics, 9:179-196.

Erteschik-Shir, N. (1986). Wh-questions and focus. Linguistics and Philosophy, 9(2):117-149.

Frellesvig, B. (2010). A History of the Japanese language. Cambridge: Cambridge University Press.

Frellesvig, B., Horn, S. W., Russell, K. L., and Sells, P. (2014). The Oxford Corpus of Old Japanese. Electronic publication, accessible at http://vsarpj. orinst.ox.ac.uk/corpus.

Groenendijk, J. and Stokhof, M. (1983). Studies in the semantics of questions and the pragmatics of answers. $\mathrm{PhD}$ thesis, University of Amsterdam.

Ikeda, T. (1975). Classical Japanese Grammar Illustrated with Texts. Tokyo: Tōhō Gakkai.

Kartunnen, L. (1977). Syntax and semantics of questions. Linguistics and Philosophy, 1:1-44.

Kayne, R. (1994). The Antisymmetry of Syntax. Cambridge, MA: MIT Press.

Kinuhata, T. and Iwata., M. (2009). かの多様性を追手 [Ka no tayosei o otte/pursuing the diversity of $k a$ ]. Ms. Osaka University.

McGinnis, M. (1999). Evidence for feature-driven A-scrambling. In Bird, S., Carnie, A., Haugen, J., and Norquest, P., editors, WCCFL 18 Proceedings, pages 364-378. Somerville, MA: Cascadilla Press.

Mitrović, M. (2014). Morphosyntactic atoms of propositional logic: a philo-logical programme. $\mathrm{PhD}$ thesis, University of Cambridge.

Miyagawa, S. (2001). The EPP, scrambling, and Wh-in-situ. In Kenstowicz, M., editor, Ken Hale: A Life in Language, pages 293-338. Cambridge, MA: MIT Press.

Miyagawa, S. (2003). A-movement scrambling and options without optionality. In Karimi, S., editor, Word Order and Scrambling, pages 177-200. Oxford: Blackwell.

Miyagawa, S. (2005). EPP and semantically vacuous scrambling. In Sabel, J. and Saito, M., editors, The Free Word Order Phenomenon, pages 181-220. Berlin: Mouton de Gruyter.

Nomura, T. (1993a). Jōdaigo no no to ga nitsuite (ge). Kokugo Kokubun, 62(703):30-49.

Nomura, T. (1993b). Jōdaigo no no to ga nitsuite (jō). Kokugo Kokubun, 62(702):1-17. 
Okimori, T. (1989). 日 本 語 史 [Nihongoshi]. Tokyo: Ōfūsha. Rizzi, L. (1997). The fine structure of the left periphery. In Haegman, L., editor, Elements of Grammar, pages 281-337. Dordrecht: Kluwer.

Partee, B. (1987). Noun Phrase Interpretation and Type-Shifting Principles. In J. Groenendijk, D. de Jongh and M. Stokhof, editors, Studies in Discourse Representation Theory and the Theory of Generalized Quantifiers, pages 115-144. Dordrecht: D. Reidel

Serafim, L. A. and Shinzato, R. (2000). Reconstructing the proto-japonic kakari musubi, . . ka . .. -(a)m-wo. 言語研究 [Gengo Kenkyu], 118:81-118.

Shimada, J. (2007). Head Movement, Binding Theory, and Phrase Structure. Unpublished monograph. MIT.

Takamiya, Y. (2005). 格助詞を伴わない力の間接疑問文について [kakujoshi o tomonawanai ka no kansetsu gimonbun ni tsuite. [on indirect questions of ka without case particles]]. 三 重大学日本語学文学 [Mie Daigaku Nihongogaku bungaku], 16:92-104.

Tokieda, M. (1954). 日本文法, 文語篇 [Nihon bunpō, Bungo hen]. Tokyo: Iwanami Shoten.

Vovin, A. (2003). A Reference Grammar of Classical Japanese Prose. London: Routledge.

Watanabe, A. (2002). Loss of overt wh-movement in Old Japanese. In Lightfoot, D. W., editor, Syntactic Effects of Morphological Change, pages 179-195. Oxford: Oxford University Press.

Watanabe, A. (2005). ミニマリストプログラム序: 生成文法のあらたな 挑戦 [Minimarisuto Puroguramu Josetsu: Seisei Bunpō no Aratana Chōsen]. Tokyo: Taishūkan.

Whitman, J. (1997). Kakarimusubi from a comparative perspective. In Sohn, H. and Haig, J., editors, Japanese/Korean Linguistics, volume 6, pages 161-178. Stanford, CA: CSLI.

Whitman, J. (2001). Kayne 1994: p. 143, fn. 3. In Alexandrova, G. M. and Arnaudova, O., editors, The Minimalist Parameter, Current issues in Linguistic Theory, pages 77-100. Amsterdam: John Benjamins.

Wrona, J. (2007). Non-movement and kakarimusubi. Paper presented at the 9th Annual International Conference of the Japan Society for Language Sciences. 